\title{
Evidence for a Robinson-like annelation during the reaction between $N$-(1-chloroalkyl)pyridinium chlorides and $N$-substituted enaminoesters
}

\author{
Jean Jacques Vanden Eynde ${ }^{* a}$, Annie Mayence ${ }^{a}$, Olga N. Kataeva ${ }^{b}$, Igor A. Litvinov ${ }^{b}$, and \\ Ernst Anders ${ }^{c}$ \\ ${ }^{a}$ University of Mons-Hainaut, Organic Chemistry Laboratory, Place du Parc 20,B - 7000 \\ Mons, Belgium E-mail: jjvde@umh.ac.be \\ ${ }^{b}$ A. E. Arbuzov Institute of Organic and Physical Chemistry, Russian Academy of Sciences, A. E. \\ Arbuzov str. 8, Kazan 420088, Russia \\ ${ }^{c}$ Institut für Organische Chemie und Makromolekulare Chemie der Friedrich-Schiller- \\ Universität Jena, Humboldtstrasse 10, D - 07743 Jena, Germany
}

(received 15 Nov 99; accepted 13 Feb 00; published on the web 21 Feb 00)

\begin{abstract}
N-Benzyl 1,4-dihydropyridine 2a and ( ) 2-benzylaminocyclohexa-1,3-diene 3 are obtained in satisfactory yields by reaction between $N$-(1-chlorobenzyl)pyridinium chloride and ethyl 3benzylaminobut-2-enoate in dichloromethane at room temperature. Mechanistic and practical considerations are discussed. Compound $\mathbf{3}$ has been unequivocally characterized by X-ray single crystal diffraction.
\end{abstract}

Keywords: Robinson annelation, 1,4-dihydropyridines, enaminoesters, cyclohexa-1,3-dienes

\section{Introduction}

A decade ago, one of our research groups reported the first synthesis of $\mathrm{N}$-(1-haloalkyl)azinium halides (1, Scheme 1) from a thionyl halide, an azine, and aldehydes. ${ }^{1}$ Prepared in situ, these salts were then subjected to substitution reactions in which both the halogen atom and the azine could be replaced by various nucleophiles. ${ }^{2}$ The reactivity of these salts makes them suitable as synthetic equivalents for the starting aldehydes. This has led to the development of new synthetic pathways for the synthesis of numerous heterocycles containing nitrogen. Among the target molecules, we focused our attention ${ }^{3,4}$ on Hantzsch dihydropyridines of the nifedipine-type. They are compounds which belong to the most studied class of calcium channel modulators used in the clinical treatment of cardiovascular diseases. ${ }^{5}$ Whereas the N-unsubstituted derivatives (2, $\mathrm{R}^{\mathrm{N}}=\mathrm{H}$ ) were obtained in excellent yields from $\mathbf{1}$ and enaminoesterss, the results were disappointing in a few cases when we attempted to prepare the N-substituted analogs. For 
example, derivative 2a $\left(\mathrm{R}=4\right.$-methoxyphenyl, $\mathrm{R}^{\mathrm{N}}=$ benzyl, Scheme 1$)$ was detected by NMR spectroscopy but it was not isolated. This finding led us to reinvestigate this particular reaction.

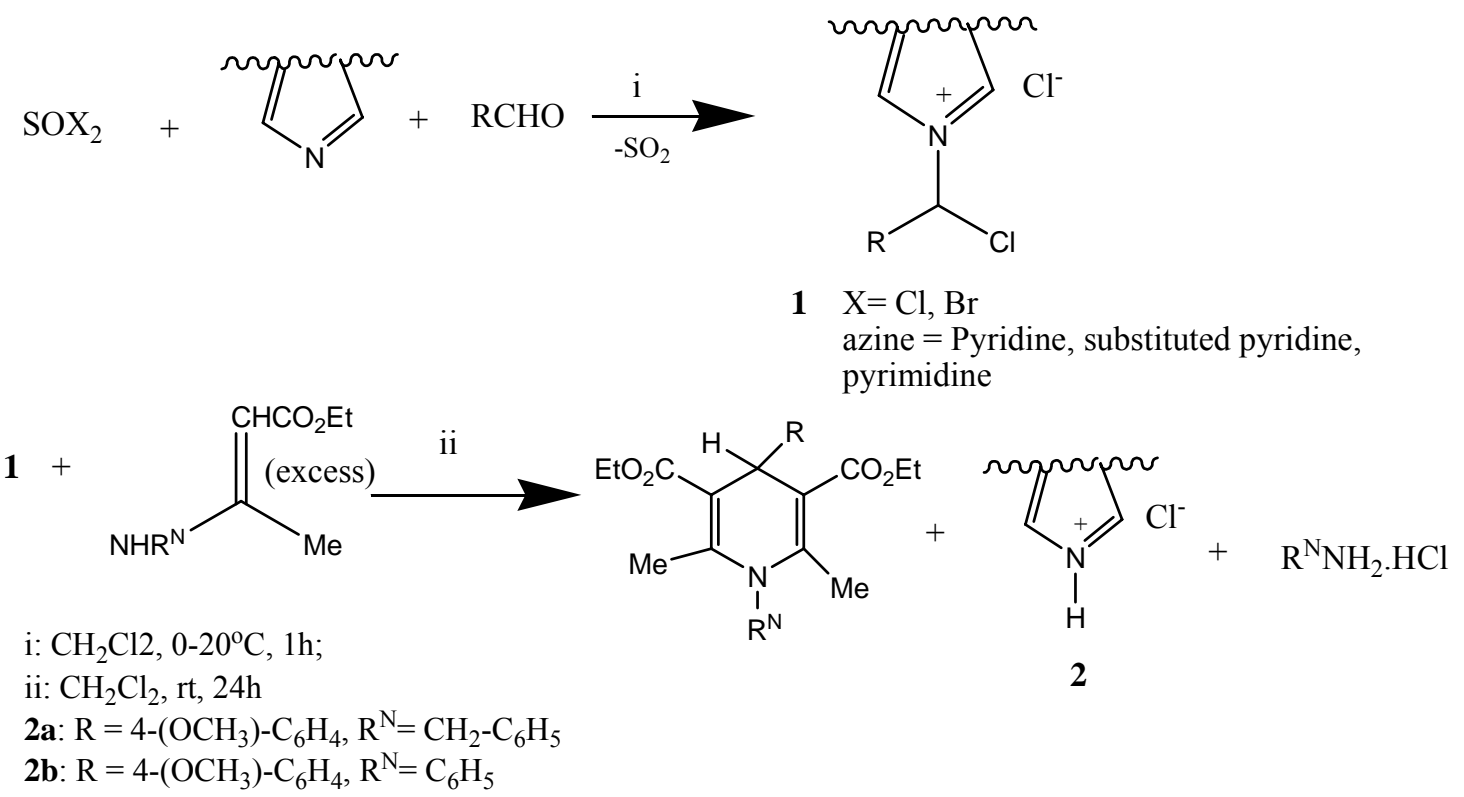

\section{Scheme 1}

\section{Experimental Section}

General Procedures. IR spectra were recorded on a Perkin-Elmer FTIR 1760K spectrophotometer. NMR spectra were recorded on a Jeol JNP-PMX 60 spectrometer $(60 \mathrm{MHz}$ for ${ }^{1} \mathrm{H}$ at $1.4 \mathrm{~T}$ ) or a Bruker AMX spectrometer $\left(300 \mathrm{MHz}\right.$ for ${ }^{1} \mathrm{H}$ and $75 \mathrm{MHz}$ for ${ }^{13} \mathrm{C}$ at $7.0 \mathrm{~T}$ ). Chemical shifts are given in ppm using TMS as internal reference. Melting points (uncorrected) were determined on a Electrothermal 9100 apparatus. Elemental analyses were carried out at the Station de Haute Belgique (Libramont-Chevigny, Belgium). Pyridine was kindly supplied by Reilly Chemicals (Tertre, Belgium). Thionyl chloride, 4-methoxybenzaldehyde, and solvents are commercially available (Acros Organics, Aldrich Co) and were used without further purification. Ethyl 3-benzylaminobut-2-enoate, ${ }^{6}$ ethyl 3-phenylaminobut-2-enoate, ${ }^{6}$ and $\mathbf{2 b}{ }^{4}$ have been described in the literature.

General experimental procedure. A solution of thionyl chloride $(0.9 \mathrm{~mL} ; 12 \mathrm{mmol})$ in dichloromethane $(25 \mathrm{~mL})$ was cooled to $0{ }^{\circ} \mathrm{C}$. Pyridine $(1.0 \mathrm{~mL} ; 12 \mathrm{mmol})$ was added dropwise followed by the addition of 4-methoxybenzaldehyde $(1.2 \mathrm{~mL} ; 10 \mathrm{mmol})$. The solution was allowed to warm up to room temperature. After confirmation ${ }^{7}$ of the formation of the salt by NMR (1 hour), the enaminoester $(40 \mathrm{mmol})$ was slowly added and the reaction mixture was stirred for $2 \mathrm{~h}$ (optimized reaction time). The precipitate, identified (NMR) as benzylamine 
hydrochloride, was discarded. The filtrate was concentrated under reduced pressure, and the residue was precipitated by addition of ethanol. Concentration of the alcoholic solution afforded the excess of the enaminoester and pyridinium hydrochloride. The solid, composed by two products (TLC, NMR), could readily and efficiently be separated by treatment with ether.

Diethyl 1-benzyl-1,4-dihydro-4-(4-methoxyphenyl)-2,6-dimethylpyridine-3,5-dicarboxylate (2a). M.p. (EtOH): $132-3{ }^{\circ} \mathrm{C}$. IR (KBr): 1697; 1678; 1576; 1386; 1202; $1153 \mathrm{~cm}^{-1}$. ${ }^{1} \mathrm{H}$ NMR $\left(\mathrm{CDCl}_{3}\right): 1.2(6 \mathrm{H}, \mathrm{q}, 7 \mathrm{~Hz}) ; 2.4(6 \mathrm{H}, \mathrm{s}) ; 3.7(3 \mathrm{H}, \mathrm{s}) ; 4.1(4 \mathrm{H}, \mathrm{t}, 7 \mathrm{~Hz}) ; 4.9(2 \mathrm{H}, \mathrm{s}) ; 5.2(1 \mathrm{H}, \mathrm{s})$; 6.7-7.2 (9 H, m) ppm. ${ }^{13} \mathrm{C}$ NMR $\left(\mathrm{CDCl}_{3}\right): 15 ; 17 ; 38 ; 50 ; 56 ; 61 ; 108 ; 114 ; 126 ; 128 ; 129 ; 130$; $138 ; 139 ; 149 ; 158 ; 169$ ppm. $\mathrm{C}_{27} \mathrm{H}_{31} \mathrm{NO}_{5}(449.55)$ Calc.: C, 72.14; H, 7.00; N, 3.12; Found: $\mathrm{C}$, $71.82 ; \mathrm{H}, 6.75 ; \mathrm{N}, 2.72$.

Diethyl 2-benzylamino-6-(4-methoxyphenyl)-4-methylcyclohexa-1,3-diene-1,5-dicarboxylate (3). M.p. (EtOH): $137-138{ }^{\circ} \mathrm{C}$. IR (KBr): $3251 ; 1723 ; 1676 ; 1627 ; 1588 ; 1275 ; 1219 \mathrm{~cm}^{-1} .{ }^{1} \mathrm{H}$ NMR (CDCl $): 1.2(3 \mathrm{H}, \mathrm{q}, 7 \mathrm{~Hz}) ; 1.3(3 \mathrm{H} ; \mathrm{q} ; 7 \mathrm{~Hz}) ; 1.8(3 \mathrm{H}, \mathrm{s}) ; 3.1(1 \mathrm{H}, \mathrm{s}) ; 3.7(3 \mathrm{H}, \mathrm{s}) ; 4.1$ $(4 \mathrm{H}, \mathrm{m}) ; 4.5(2 \mathrm{H}, \mathrm{s}) ; 4.6(1 \mathrm{H}, \mathrm{s}) ; 6.2(1 \mathrm{H}, \mathrm{s}) ; 6.7-7.4(9 \mathrm{H}, \mathrm{m}) ; 9.3(1 \mathrm{H}, \mathrm{br}) \mathrm{ppm} .{ }^{13} \mathrm{C}$ NMR $\left(\mathrm{CDCl}_{3}\right): 14 ; 15 ; 25 ; 40 ; 47 ; 53 ; 55 ; 59 ; 61 ; 88 ; 113 ; 118 ; 126 ; 127 ; 128 ; 129 ; 136 ; 139 ; 143$; $154 ; 158 ; 170 ; 171$ ppm. $\mathrm{C}_{27} \mathrm{H}_{31} \mathrm{NO}_{5}$ (449.55) Calc.: C, 72.14; H, 7.00; N, 3.12; Found: C, 71.87; $\mathrm{H}, 7.42 ; \mathrm{N}, 3.07$.

X-Ray structure determination. Table 1 lists the experimental conditions and the final refinement parameters for 3 . Stability of the crystals and of the experimental conditions was checked every $2 \mathrm{~h}$ using three control reflections, while the orientation was monitored every 200 reflections by centering two standards. Linear decay correction was applied, total loss of intensity being equal to $7 \%$. No absorption correction was necessary. Corrections for Lorentz and polarization effects were applied. The phase problem was solved by direct methods using program SIR. ${ }^{8}$ The structure was developed by difference-Fourier calculations interspersed with cycles of full-matrix least-squares refinements. All hydrogen atoms were located from difference Fourier maps and refined isotropically with fixed thermal parameters. Interestingly the selected crystal had noncentrosymmetrical space group, thus only one enantiomer was present. Its absolute configuration, determined via anomalous dispersion effects, was found to be $\mathrm{C} 3_{/ \mathrm{S} /}, \mathrm{C} 4_{/ \mathrm{R} /}$ with the probability of $90 \%$ according to the Hamilton test ${ }^{9}$ : for direct structure $\mathrm{R}=0.05554$, $\mathrm{R}_{\mathrm{w}}=0.06335$, number of variables 391 , number of reflections in least-squares 1902 , max. $) / \Phi=$ 0.07 , goodness of fit 2.099 , for inverse structure $\mathrm{R}=0.05558, \mathrm{R}_{\mathrm{w}}=0.06339$, max. $) / \Phi=0.13$, goodness of fit 2.101. All calculations were carried out on Alpha Station 200 using programs MOLEN. ${ }^{10}$ The drawing of the molecule was made using the program PLATON. ${ }^{11}$ Crystallographic data (excluding structure factors) for the structure 3 reported in this paper have been deposited at the Cambridge Crystallographic Data Center as supplementary publication number CCDC 137227. Copies of the data can be obtained free of charge on application to CCDC, 12 Union Road, Cambridge CB2 1EZ, UK (Fax: + 441223336 033; E-mail : deposit@ccdc.cam.ac.uk). 
Table 1. Crystal data and structure refinement parameters for the X-ray analysis of 3

\begin{tabular}{|c|c|}
\hline Molecular Formula & $\mathrm{C}_{27} \mathrm{H}_{31} \mathrm{NO}_{5}$ \\
\hline Crystal color, shape & Colorless, prism \\
\hline Approx. Crystal dimensions, mm & $0.1 \times 0.2 \times 0.5$ \\
\hline Formula weight & 449.55 \\
\hline Temperature, ${ }^{\circ} \mathrm{C}$ & 20 \\
\hline Crystal system & Orthorhombic \\
\hline Space group & $\mathrm{P} 2{ }_{1} 2_{1} 2_{1}$ \\
\hline \multicolumn{2}{|l|}{ Cell constants } \\
\hline $\mathrm{a}, \AA$ & $8.279(3)$ \\
\hline $\mathrm{b}, \AA$ & $15.517(5)$ \\
\hline $\mathrm{c}, \AA$ & $18.958(7)$ \\
\hline Z & 4 \\
\hline $\mathrm{V}, \AA^{3}$ & $2435(2)$ \\
\hline$\mu_{\text {calc. }, \mathrm{cm}^{-1}}$ & 6.44 \\
\hline$\rho_{\text {calc. }} \mathrm{g} \cdot \mathrm{cm}^{-3}$ & 1.23 \\
\hline $\mathrm{F}(000)$ & 960 \\
\hline Radiation & $\mathrm{Cu} \mathrm{K} \alpha(\lambda=1.54178 \AA)$ \\
\hline Diffractometer & Enraf-Nonius CAD4 \\
\hline $2 \theta$ range, deg. & 152 \\
\hline Scan type & $\omega / 2 \theta$ \\
\hline $\mathrm{h}, \mathrm{k}, 1$ range collected & $0 \rightarrow 10,-19 \rightarrow 0,0 \rightarrow 23$ \\
\hline Reflections collected & 2853 \\
\hline Reflections observed, $\mathrm{F}^{2 \geq} 3 \sigma\left(\mathrm{F}^{2}\right)$ & 2006 \\
\hline No. of reflections in least-squares & 1902 \\
\hline No. of parameters & 391 \\
\hline Goodness-of-fit & 2.1 \\
\hline $\mathrm{R}=\Sigma \quad \Delta \mathrm{F} \quad / \Sigma \quad \mathrm{F}_{\mathrm{o}}$ & 0.056 \\
\hline $\mathrm{R}_{\mathrm{w}}=\left[\Sigma \omega(\Delta \mathrm{F})^{2} / \omega^{F_{\mathrm{a}}^{2}}\right]^{1 / 2}$ & 0.063 \\
\hline Weighting scheme & $4 F_{a}^{2} /\left(a(I)^{2}+\left(0.04 F_{0}^{2}\right)\right)^{2}$ \\
\hline
\end{tabular}

\section{Results and Discussion}

At the end of the procedure described in the experimental section, the expected 1,4dihydropyridine 2 , as indicated by the spectral data, ${ }^{4}$ was isolated in $36 \%$ yield by evaporation of the ether solution. The ether-insoluble derivative (3) has the same molecular weight $(\mathrm{m} / \mathrm{z}=$ 
449 ) as 2 and was isolated in $29 \%$ yield. Its IR spectrum reveals the presence of a secondary amine $\left(3251 \mathrm{~cm}^{-1}\right)$ and a (non conjugated) carbonyl group $\left(1723 \mathrm{~cm}^{-1}\right)$. The ${ }^{1} \mathrm{H}$ NMR spectrum is indicative of an unsymmetrical and complex product with two non equivalent ester functions. In the ${ }^{13} \mathrm{C}$ NMR spectrum, 23 signals are detected. To establish the structure of 3 , a sample was investigated by X-ray single crystal diffraction. Compound 3 can be described as diethyl 2benzylamino-6-(4-methoxyphenyl)-4-methylcyclohexa-1,3-diene-1,5-dicarboxylate.

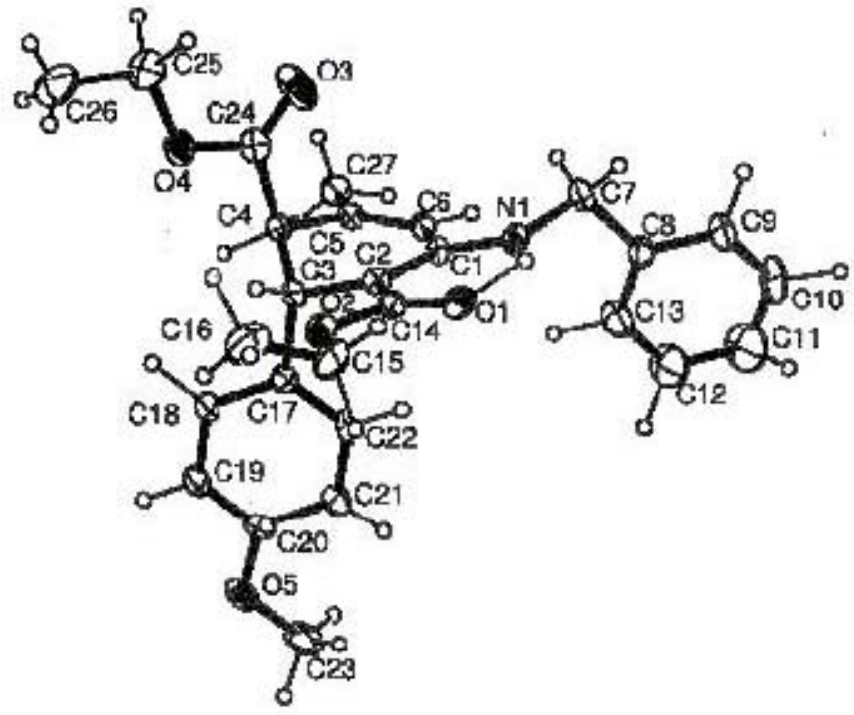

The central unsaturated 6-membered ring adopts an unsymmetrical boat conformation, which is determined by two planar fragments twisted around the single bond $\mathrm{C} 1-\mathrm{C} 6$. The bond lengths in the ring (Table 2) reveal the "classical" trends usually observed for unsaturated systems: two double bonds $\mathrm{C} 1-\mathrm{C} 2$ and $\mathrm{C} 5-\mathrm{C} 6$ are nearly coplanar and elongated, while the single bond in between is shortened. The $\mathrm{C}\left(\mathrm{sp}^{3}\right)-\mathrm{C}\left(\mathrm{sp}^{2}\right)$ bonds are shorter than the $\mathrm{C}\left(\mathrm{sp}^{3}\right)-\mathrm{C}\left(\mathrm{sp}^{3}\right)$ bonds. The methoxybenzyl group at $\mathrm{C} 3$ is twisted around the $\mathrm{C} 3-\mathrm{C} 17$ bond by $25^{\circ}$ to avoid steric interactions with the central 6-membered ring and the neighboring ethoxycarbonyl substituent at $\mathrm{C} 2$. This ethoxycarbonyl group forms a conjugated planar fragment $\mathrm{C} 1=\mathrm{C} 2-\mathrm{C} 14=\mathrm{O} 1$, the central single $\mathrm{C} 2-\mathrm{C} 14$ bond in this fragment is with $1.425(5) \AA$ short and double bonds are elongated. In particular, the $\mathrm{C} 14=\mathrm{O} 1$ bond (1.223(4) $\AA$ ) is $0.03 \AA$ longer than the $\mathrm{C}=\mathrm{O}$ bond of the second ethoxycarbonyl substituent which exhibits a skew position with the torsion angle O3-C24-C4-C5 being $-22.8^{\circ}$. The $\mathrm{N}-\mathrm{H}$ bond of the benzylamino substituent is in an eclipsed position respective to the $\mathrm{C} 1=\mathrm{C} 2$ bond of the central ring. This permits a strong intramolecular hydrogen bond with formation of a 6-membered cycle. The parameters of the hydrogen bond are as follows: N1H1...O1, N1-H1 1.05(4), H1...O1 1.86(5) $\AA, \pi \mathrm{N} 1-\mathrm{H} 1 \ldots \mathrm{O} 1127^{\circ}$. 
Table 2. Principal geometrical parameters in compound 3

\begin{tabular}{cccc}
\hline \multicolumn{2}{c}{ Bond lengths in $\AA$} & \multicolumn{2}{c}{ Valence and torsion angles } \\
\hline $\mathrm{C} 1-\mathrm{C} 2$ & $1.382(5)$ & $\mathrm{C} 6 \mathrm{C} 1 \mathrm{C} 2$ & $120.1(3)$ \\
$\mathrm{C} 2-\mathrm{C} 3$ & $1.521(5)$ & $\mathrm{C} 1 \mathrm{C} 2 \mathrm{C} 3$ & $118.3(3)$ \\
$\mathrm{C} 3-\mathrm{C} 4$ & $1.534(5)$ & $\mathrm{C} 2 \mathrm{C} 3 \mathrm{C} 4$ & $110.6(3)$ \\
$\mathrm{C} 4-\mathrm{C} 5$ & $1.518(5)$ & $\mathrm{C} 3 \mathrm{C} 4 \mathrm{C} 5$ & $112.0(3)$ \\
$\mathrm{C} 5-\mathrm{C} 6$ & $1.327(5)$ & $\mathrm{C} 4 \mathrm{C} 5 \mathrm{C} 6$ & $118.9(3)$ \\
$\mathrm{C} 1-\mathrm{N} 1$ & $1.354(4)$ & $\mathrm{C} 5 \mathrm{C} 6 \mathrm{C} 1$ & $122.3(3)$ \\
$\mathrm{N} 1-\mathrm{C} 7$ & $1.459(5)$ & $\mathrm{C} 6 \mathrm{C} 1 \mathrm{C} 2 \mathrm{C} 3$ & $3.9(5)$ \\
$\mathrm{C} 14=\mathrm{O} 1$ & $1.223(4)$ & $\mathrm{C} 1 \mathrm{C} 2 \mathrm{C} 3 \mathrm{C} 4$ & $-35.1(4)$ \\
$\mathrm{C} 14-\mathrm{O} 2$ & $1.353(5)$ & $\mathrm{C} 2 \mathrm{C} 3 \mathrm{C} 4 \mathrm{C} 5$ & $47.6(4)$ \\
$\mathrm{C} 14-\mathrm{C} 2$ & $1.425(5)$ & $\mathrm{C} 3 \mathrm{C} 4 \mathrm{C} 5 \mathrm{C} 6$ & $-31.6(5)$ \\
$\mathrm{C} 3-\mathrm{C} 17$ & $1.535(5)$ & $\mathrm{C} 4 \mathrm{C} 5 \mathrm{C} 6 \mathrm{C} 1$ & $-0.8(6)$ \\
$\mathrm{C} 24=\mathrm{O} 3$ & $1.192(5)$ & $\mathrm{C} 5 \mathrm{C} 6 \mathrm{C} 1 \mathrm{C} 2$ & $16.1(6)$ \\
$\mathrm{C} 24-\mathrm{O} 4$ & $1.331(5)$ & $\mathrm{C} 1 \mathrm{~N} 1 \mathrm{C} 7 \mathrm{C} 8$ & $-101.1(4)$ \\
$\mathrm{C} 24-\mathrm{C} 4$ & $1.516(5)$ & $\mathrm{N} 1 \mathrm{C} 7 \mathrm{C} 8 \mathrm{C} 13$ & $38.4(5)$ \\
\hline
\end{tabular}

Since the molecule 3 contains a lot of $\mathrm{C}-\mathrm{H}$ groups and $\mathrm{O}$ acceptors, one may expect intermolecular C-H...O interactions present in a vast number of crystal structures. ${ }^{12}$ However, we did not observe $\mathrm{C}-\mathrm{H}$...O intermolecular contacts shorter than 2.6 $\AA$. Moreover, there are many short intramolecular $\mathrm{C}-\mathrm{H}$...O contacts (Table 3), in which the $\mathrm{H}$ and $\mathrm{O}$ atoms are usually separated by three or four covalent bonds. The $\mathrm{C}$ - H contacts, treated as weak hydrogen bonds, are considered to play a significant role in crystal packing and molecular conformations. ${ }^{13-15}$ Many short contacts in molecule 3, listed in Table 3, are imposed by the inherent geometry of the corresponding fragments. However, observed deviations of geometrical parameters from their "ideal" values tend to bring $\mathrm{H}$ and $\mathrm{O}$ atoms closer for most of the detected contacts. It should be mentioned that the positions of the hydrogen atoms were refined with sufficient accuracy in this structure, thus the deviation of the $\mathrm{C}-\mathrm{C}-\mathrm{H}$ bond angles from the tetrahedral value to $100(2)^{\circ}$ or even less may therefore be indicative of hydrogen bond formation. 
Table 3. Short intramolecular C-H...O contacts in compound 3

\begin{tabular}{lrcc}
\hline \multicolumn{2}{c}{ Short contacts in $\AA$} & \multicolumn{2}{c}{ Angles at hydrogen atoms in deg. } \\
\hline $\mathrm{O} 1 \ldots \mathrm{H} 152$ & 2.43 & $\mathrm{C} 15-\mathrm{H} 152 \ldots \mathrm{O} 1$ & 89 \\
$\mathrm{O} 2 \ldots \mathrm{H} 162$ & 2.43 & $\mathrm{C} 16-\mathrm{H} 162 \ldots \mathrm{O} 2$ & 75 \\
$\mathrm{O} 2 \ldots \mathrm{H} 3$ & 2.39 & $\mathrm{C} 3-\mathrm{H} 3 \ldots \mathrm{O} 2$ & 106 \\
$\mathrm{O} 3 \ldots \mathrm{H} 251$ & 2.34 & $\mathrm{C} 25-\mathrm{H} 251 \ldots \mathrm{O} 3$ & 94 \\
$\mathrm{O} 4 \ldots \mathrm{H} 4$ & 2.37 & $\mathrm{C} 4-\mathrm{H} 4 \ldots \mathrm{O} 4$ & 78 \\
$\mathrm{O} 4 \ldots \mathrm{H} 263$ & 2.35 & $\mathrm{C} 26-\mathrm{H} 263 \ldots \mathrm{O} 4$ & 77 \\
\hline
\end{tabular}

The torsion angle $\mathrm{H}-\mathrm{C}\left(\mathrm{CO}_{2} \mathrm{Et}\right)-\mathrm{C}(\mathrm{Ar})-\mathrm{H}$ is estimated to be $-74.7^{\circ}$ in the solid phase, a result that is comparable to the value that can be calculated ${ }^{16}$ from the NMR data by the equations of Karplus $\left({ }^{3} \mathrm{~J} \mathrm{H}-\mathrm{H}<1 \mathrm{~Hz}\right)$. This indicates a trans arrangement of the hydrogen atoms and characterizes a considerable flattening of the cycle.

We can rule out the interconversion between $\mathbf{2}$ and $\mathbf{3}$ as being responsible for the formation of $\mathbf{3}$ since a mixture of $\mathbf{2}$ and $\mathbf{3}$ does not change slightest when the reaction time is modified ( $2 \mathrm{~h}$ to 24 h) nor is affected when the temperature is raised to the reflux point of the solvent (acetonitrile or chlorobenzene). We therefore suggest (Scheme 2) - supported by semiempirical calculations, vide infra - that the cationic intermediate 4 , resulting from the interaction between the pyridinium salt and two molecules of the enaminoester, is the key intermediate in the formation of both 2 and 3. Heterocyclization could yield compound 2, whereas an imine-enamine tautomerization ${ }^{17}$ should be responsible for the formation of $\mathbf{3}$ via a Robinson-like annelation. In agreement with such a mechanism, preparation of a cyclohexadiene should be disfavored when starting from ethyl 3-phenylaminobut-2-enoate because of the poor electron-donating effect of the nitrogen atom in the enamine form 5. This was experimentally verified. The reaction with 1 affords the 1,4-dihydropyridine $\mathbf{2 b}$ as the only product $(25 \%$ yield, hydrolysis of the enaminoester is the limiting side-reaction). 

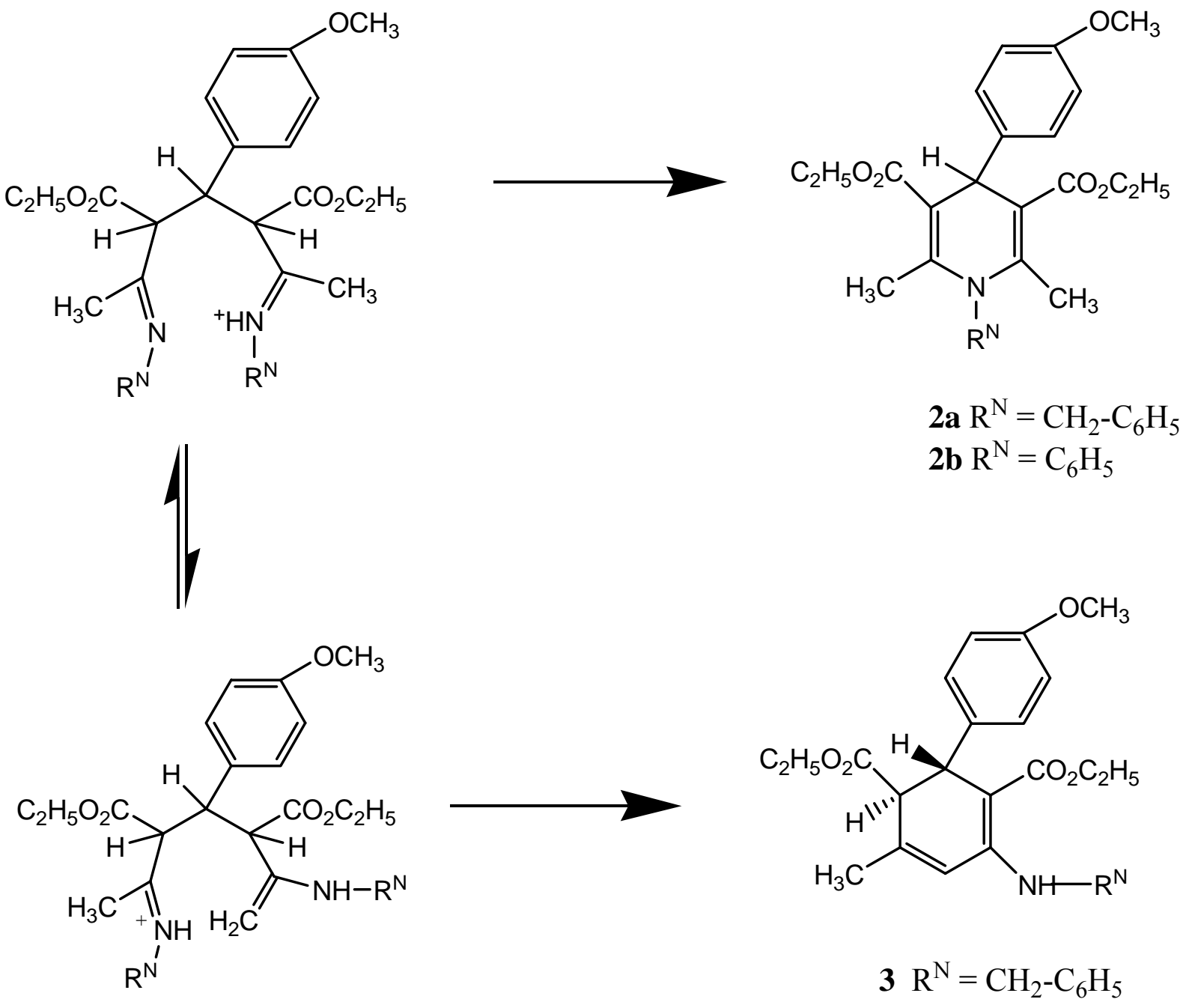

5

Scheme 2 


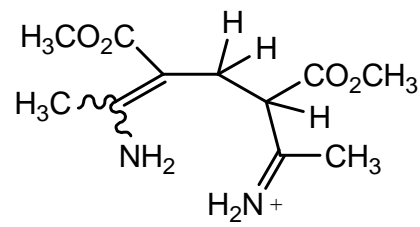

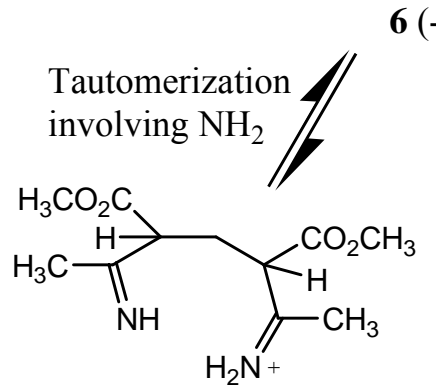

$7(0.0 \mathrm{kcal} / \mathrm{mol})$

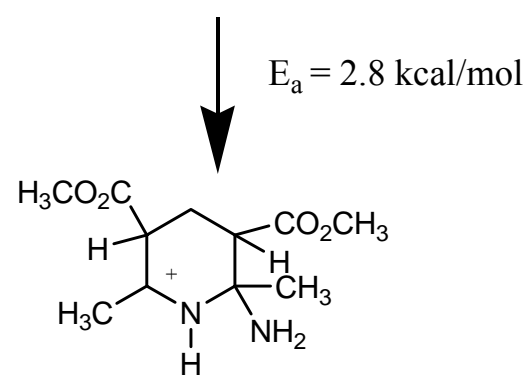

$9(-9.5 \mathrm{kcal} / \mathrm{mol})$<smiles>COC(=O)C1(C)CC(C(C)=O)=C(C)NC1(N)N</smiles>

$11(-164.5 \mathrm{kcal} / \mathrm{mol})$<smiles>CC(=O)C1=C(C)NC(C)=C(C(=O)OCCCCN)C1</smiles>

13(-155.2 kcal/mol)

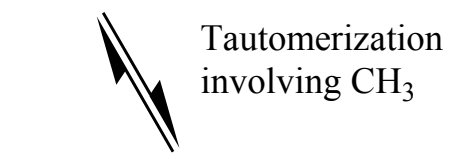<smiles>C=C(N)C(CC(C(C)=O)C(=O)OC)(C(C)=N)C(=O)O</smiles>

$8(3.2 \mathrm{kcal} / \mathrm{mol})$

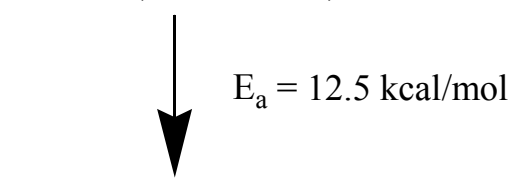<smiles>COC(=O)C1(C)CC(C(C)=O)(C(=O)OC)C(N)NC1N</smiles>

$10(-10.1 \mathrm{kcal} / \mathrm{mol})$

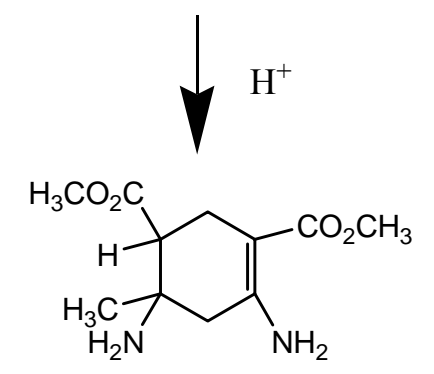

$12(-156.3 \mathrm{kcal} / \mathrm{mol})$

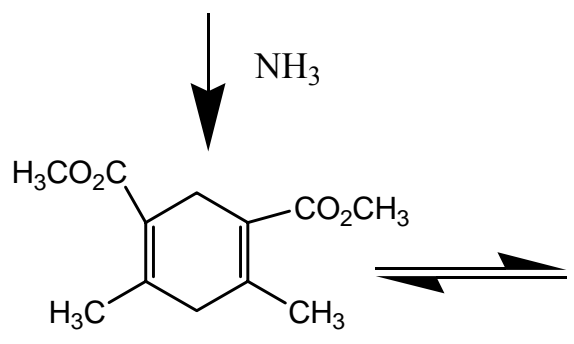

$14(-154.2 \mathrm{kcal} / \mathrm{mol})$<smiles>CC(=O)C1=C(N)C=C(C)C(C(C)=O)C1</smiles>

16(-149.8 kcal/mol)

\section{Scheme 3}


The proposed mechanistic pathways have been simulated by the semiempirical PM3 ${ }^{18}$ method (Scheme 3). ${ }^{19}$ The initial step is the formation of $\mathbf{6}$, which is obtained from the interaction between of $1(\mathrm{R}=\mathrm{H})$ and two molecules of the model enaminoester, $\mathrm{MeCO}_{2} \mathrm{C}(\mathrm{H})=\mathrm{C}(\mathrm{Me}) \mathrm{NH}_{2}{ }^{20}$ Compound 6 allows tautomerization in two directions: a) formation of 7, which contains a nucleophilic imine group; and b) formation of $\mathbf{8}$, which exhibits an enamine moiety. Both structures are quite similar in energy, 8 turns out to be just $3 \mathrm{kcal} / \mathrm{mol}$ more energetic than 7 . The latter is responsible for the formation of $\mathbf{9}$ and the further steps which lead to 13. The alternative route (via 10 and 12) to yield 14 and 15 depends on the availability and nucleophilicity of the enamine C-atom. Furthermore, the activation barrier for the cyclization reaction $7 \rightarrow \mathbf{9}\left(\mathrm{E}_{\mathrm{a}}=2.8\right.$ $\mathrm{kcal} / \mathrm{mol})$ is lower than for the alternative pathway $\mathbf{8} \rightarrow \mathbf{1 0}\left(\mathrm{E}_{\mathrm{a}}=12.5 \mathrm{kcal} / \mathrm{mol}\right)$. Both barriers can be surmounted under the applied reaction conditions. These semiempirical results allow the following general interpretation: the formation of the dihydropyridine $\mathbf{1 3}$ is the dominant feature of our cyclization reactions. Nevertheless and as already mentioned, structures $\mathbf{7}$ and $\mathbf{8}$ do not differ significantly in energy. Therefore, the second channel remains open, depending on subtle sterical and electronical effects of the substituents $\mathrm{R}$ and $\mathrm{R}^{\mathrm{N}}$. For example, bulky substituents $\mathrm{R}^{\mathrm{N}}$ (e.g. $\mathrm{CH}_{2} \mathrm{C}_{6} \mathrm{H}_{5}$ ) at both nitrogens of 7 will hinder the ring closure reaction more efficiently than in case of the counterpart, the $\mathbf{8}$ to $\mathbf{1 0}$ cyclization.

\section{Conclusions}

As reported by some research groups, aminocyclohexadienes with different double bonds locations have been obtained ${ }^{17}$ in low yields, but as major product besides N-substituted 1,4dihydropyridines, by the interaction between 2-(hetero)arylmethylene-3-oxobutanoates and 3benzylaminobut-2-enoates. In contrast, the multi-component reaction described here constitutes a convenient method for the preparation, in fairly acceptable yields, of both a 2benzylaminocyclohexa-1,3-diene 3 and the isomeric N-benzyl 1,4-dihydropyridine $\mathbf{2 b}$, whose separation is not a tedious process. Our results therefore constitute a novel example of the efficiency and advantages of using $\mathrm{N}$-(1-haloalkyl)azinium halides instead of the starting aldehydes in a procedure that is characterized by its simplicity. The detection and isolation of $\mathbf{3}$ also enable us to explain the variations of yields previously observed ${ }^{4}$ during the preparation of other N-substituted 1,4-dihydropyridines from $\mathrm{N}$-(1-haloalkyl)pyridinium chlorides and $\mathrm{N}$ substituted enaminoesters.

\section{Acknowledgments}

One of us (E.A.) thanks the "Fonds der Chemischen Industrie" (Germany) for a financial support. 


\section{References}

1. Anders, E.; Tropsch, J.G. Bull. Soc. Chim. Belg. 1987, 96, 719.

2. Anders, E.; Vanden Eynde, J. J.; Wermann, K. Advances in Heterocyclic Chemistry, in press.

3. Vanden Eynde, J. J.; D’Orazio, P.; Mayence, A.; Maquestiau, A.; Anders, E. Tetrahedron 1992, 48, 1263.

4. Vanden Eynde, J. J.; Mayence, A.; Maquestiau, A.; Anders, E. Synth. Commun. 1992, 22, 3291.

5. Bossert, F.; Meyer, H.; Wehinger, E. Angew. Chem., Int. Ed. 1981, 20, 762.

6. Decombe, J. Ann. Chim. (Paris) 1932, 18, 81.

7. Maquestiau, A.; Anders, E.; Mayence, A.; Vanden Eynde, J. J. Chem. Ber. 1991, 124, 2013.

8. Altomare, G.; Cascarano, C.; Giacovazzo, D.; Virerbo, V. Acta Crystallogr. 1991, A47, 744.

9. Hamilton, W. C. Acta Crystallogr. 1965, 18, 502.

10. Straver L.; Schierbeek A. J. in MOLEN. Structure Determination System; Nonius B.V. 1994 ; V.1,2.

11. Johnson, C.K. in ORTEP. Report ORNL-3794; Oak Ridge National Laboratory, Tennessee, USA, 1965.

12. Taylor, R.; Kennard, O. J. Am. Chem. Soc. 1982, 104, 5063.

13. Desiraju, G. R. Acc. Chem. Res. 1991, 24, 290.

14. Desiraju, G. R. Acc. Chem. Res. 1996, 29, 441.

15. Steiner T.; Saenger, W. J. Am. Chem. Soc. 1992, 114, 10146.

16. Kemp, W. in Organic Spectroscopy, 3rd Edition, MacMillan Press Ltd., London, UK, 1991.

17. (a) Natale, N. R.; Hope, H. J. Heterocycl. Chem. 1986, 23, 711. (b) Caballero, E.; Puebla, P.; Menarde, M.; San Feliciano, A. Tetrahedron 1993, 49, 10079. (c) Muceniece, D.; Zandersons, A.; Lusis, V. Bull. Soc. Chim. Belg. 1997, 106, 467.

18. Stewart, J. J. P. J. Comput. Aided Molec. Design 1990, 4, 1.

19. More detailed information (geometrical and energetical parameters, additional calculations) can be obtained from the authors on request.

20. The formation of compound $\mathbf{6}$ can be rationalized by a well-balanced influence of stereoelectronic effects and the nucleofugicity of the pyridine moiety in 1. Cf. ref. 2. 